\title{
ENGLISH TRANSLATION OF THE QURAN BY WOMEN: \\ THE CHALLENGES OF "GENDER BALANCE" IN AND THROUGH LANGUAGE
}

\author{
Rim Hassen \\ University of Warwick
}

\begin{abstract}
This paper aims to explore and discuss how women translators of the Quran have dealt with the patriarchal linguistic elements in the source text by focusing on two main challenges of translation. First the problem of gender agreement differences between the target and the source language. Because Arabic is highly gendered and English is not, many feminine nouns, pronouns and verbs become invisible in English and as result the "gender balance" created in original could be lost in the translation. The second challenge they face lies in the use of masculine nouns and pronouns in the generic sense, which as many feminists argued assumes generic human to be male and excludes the "human woman." The four female translators, discussed in this paper, seem to react differently to these linguistic and translational challenges revealing a "feminine language" on one hand and reproducing the dominant male voice on the other.
\end{abstract}

\section{Résumé}

Cet article explore et discute la façon dont les traductrices du Coran ont traduit le langage patriarcal de l'arabe vers l'anglais, en se concentrant sur deux principaux problèmes. Le premier concerne la traduction du genre grammatical de la langue source vers la langue cible. Contrairement à l'arabe, l'anglais ne connaît pas de genre grammatical ou formel, ce qui signifie que de nombreux noms, pronoms et verbes au féminin peuvent devenir invisibles dans le texte traduit. Parmi les conséquences de cette profonde différence sont la disparition des images féminines et la perte de « l'équilibre des genres » établi dans le texte original. Le deuxième problème réside dans l'usage générique attribué au masculin, ce qui, d'un point de vue féministe, présente l'homme 
comme le modèle de "l'être humain » et exclut la femme comme "être humaine». Les quatre traductrices, présentées dans cet article, semblent réagir différemment à ces difficultés, révélant une " écriture féminine » d'une part, et imitant le langage patriarcal de l'autre.

Keywords: Women translators of the Quran. Feminist critique of language. Grammatical gender. Inclusive/exclusive language. Religious text translation.

Mots clés: Femmes traductrices du Coran. Critique féministe du langage. Genre grammatical. Langage inclusif / exclusif. Traduction de textes religieux. 


\section{Introduction}

In recent years language has become a major battle ground for reclaiming gender equality as feminist writers and translators' concern with patriarchal language drew attention to sex discrimination in and through language. Their critique has helped to question the politics and the impacts of grammatical and linguistic rules used in various text types including the religious and the sacred. Because they were born in patriarchal societies, ancient religious texts, such as the Quran have become famous for their predominantly patriarchal tone, which for today's readers seem to exclude and discriminate against women. In today's context, where changes in cultural and social norms are directing language to be more inclusive, a growing number of women and men are finding the male-centred language as well as the masculine concept of the divine alienating. The aim of this paper is to discuss how women translators of the Quran have dealt with the patriarchal linguistic elements in the Quranic text and how this reflects the cultural, social and religious environment in which they live.

Women's involvement in Quran translation into English is a very recent phenomenon. In fact, the first English translation of the Quran by a woman was published in 1995, almost four hundred years after Alexander Ross published the first ever English version of the Holy text in 1649. Today there are five female-male team English translations of the Quran, mainly between husbands and wives. In this paper I will focus on the four individual versions by women, namely The Quran, Arabic Text with Corresponding English Meaning (1995) by Umm Muhammad, known under the pseudonym of Saheeh International, an American convert to Islam who lives in Saudi Arabia; The Light of Dawn (1999) by Camille Adams Helminski, also an American convert based in the United States; The Holy Quran: Translation with Commentary (2006) by the famous Iranian writer and poetess Tahereh Saffarzadeh; and finally The Sublime Quran (2007) by Laleh Bakthiar, an Iranian-American convert to Islam who lives in the United States.

Taking into consideration feminist critique of conventional language and modern day concerns with gender equality, the four women translators of 
the Quran face similar challenges of translation. One of the first lies in the difference in gender agreement between the target and the source language. Because Arabic is a highly gendered language and English is not, transferring the feminine form of nouns, pronouns and verbs from one text to the other is often difficult. As a result gender-specific meanings essential for ensuring women's visibility and constructing feminine imagery could lose their significance in the target text. To solve this problem feminist translators such as Suzanne de Lotbinière-Harwood and Barbara Godard have developed a number of innovative techniques when translating from French into English. The question, however, is whether such strategies could be applicable to the sacred text of Islam? And what measures will women translators of the Quran take in order to ensure the transfer of feminine meanings and images into the target text and to maintain what Michael Sells (1999: 5) describes as a "gender balance" in the Quranic text?

The second challenge facing women translators of the Quran lies in the male-biased linguistic elements in the source language. Like the Bible, the Quran uses predominantly masculine nouns and pronouns in the generic sense, which raises the question whether the excessive use of male-centered words in many religious texts is an affirmation of God's intention for gender relations, or is He/She accommodating to a particular societal structure? The answer to this question has divided Bible translators and sparked a heated debate on the use of gender neutral (attempts to eliminate any reference to gender whether of the Deity or people) or gender-inclusive language (seeks to use terms that are inclusive of both genders) in translated religious text. In the field of Quran translation, the debate about inclusive or gender neutral language has not yet achieved the same visibility as in Bible translation. There are, however, signs of change as both Helminski and Bakhtiar seem to consistently reject and avoid exclusive and male-centered words. In sharp contrast, Umm Muhammad and Saffarzadeh seem to reproduce and to maintain patriarchal language, which could be read as a reflection of their cultural, social and religious environment.

\section{Woman, Language and Reality}

Since the 1960s and 1970s many feminist theorists have become critical of the inherent bias of the English language towards the masculine gender, a bias that in their view has contributed to the exclusion, oppression and subordination of women. In her book Man Made Language (1980) Dale Spender notes that the 1850 Act of Parliament, which legally confirmed that 'he' stood for 'she', was passed primarily in order to "promote the primacy of the male 
as a category" and to construct a male reality for the world that females had to adhere to (1980:147). She also asserts that the dominant male group have "constructed sexism and developed a language trap in their own interest" (ibid.). At the core of Spender's critique lies the conviction that the language we use reflects, and in turn, shapes the way we construct our experience of the world as it is posited by the Sapir-Whorf hypothesis. Spender for instance explains that when the term 'man' is used in a generic sense, the reader pictures or forms a "mental image" of a "male" instead of "humankind." This in her view makes women invisible (1980:147). Mary Daly, who shares similar views, also believes that the English language is male-oriented. Like Spender, she argues that language has originated from men's experiences and is used to perpetuate their interests. Women are, as a result, excluded from meaning and thus from power, both in, and by means of, language. Deborah Cameron sums up their works as arguing that women:

live and speak within the confines of man-made symbolic universe. They must cope with the disjunction between the linguistically-validated male world view and their own experience, which cannot be expressed in male language. Indeed, since language determines reality, women may be alienated not only from language but also from the female experience it fails to encode.

(Cameron 1985: 93)

Women's exclusion from meaning and reality presents them as the "Other" and as the object of a male subject as Simone de Beauvoir argued in The Second Sex.

One of the earlier responses to the problem of patriarchal bias in the English language was voiced by Casey Miller and Kate Swift in their article "De-sexing the English language" (1972) and later in their book Words and Women (1977). Miller and Swift strongly criticized the use of words such as "mankind," which defines both men and women as male and assumes the generic human to be male (1977: 16-20). In an attempt to make the English language more inclusive of women, they proposed a range of non-sexist alternatives to the offending lexical and grammatical forms in The Handbook of Non-Sexist Writing (1980). For other feminists such as Zusette Haden Elgin correcting existing language did not provide the answer to women's exclusion from reality. In 1984, she published a novel titled Native Tongue, its plot revolved around a group of women, all linguists, who engaged in constructing a language specifically designed to express the perceptions of "human women." She named this language Láadan. Elgin explains that she created a woman's language because existing human languages are inadequate to express women's realities. English, she writes: 
expresses the experiences of the men and especially the linguist men relatively well and completely, creating in them a sense of justification and self righteousness. For the linguist women, on the other hand, the available language fails to match their set of experiences, and they feel a host of negative emotions. (Elgin 1984: 312)

Elgin documented her new language in the First Dictionary and Grammar of Láadan, published in 1988. One of the most interesting aspects of this new language is that it contains a variety of words describing experiences specifically related to women. For instance, the linguist distinguishes various types and stages of pregnancy. While in English the word 'pregnant' covers them all, Elgin introduced words like 'lewidan' to describe a woman who is pregnant for the first time, 'widazhad' for being pregnant late in term and eager for the end, 'lóda' to refer to being pregnant wearily and 'lalewida' meaning to be pregnant joyfully. She does the same with other words reserved to women such as 'to menstruate' and 'to menopause.' Years after its creation, láadan remains, however, a fictional and an unknown language.

Other responses to patriarchal language could be found in the works of a number of women writers, who invented ingenious solutions to challenge male bias and to make the feminine visible in language. For instance as an alternative to the use of generic 'he,' writers such as Marge Piercy, June Arnold and Dorothy Bryant came up with new pronouns. In her novel Woman on the Edge of Time (1976), Marge Piercy uses 'person' as subject pronoun and 'per' as object pronoun and possessive; in The Cook and Carpenter (1973), June Arnold introduces 'na,' 'nan,' and 'naself;' and finally in her novel The Kin of Ata Waiting for You (1971), Dorothy Bryant proposes 'kin,' as unmarked for either gender or number. Moreover, to solve the problem of the lack of feminine visibility in the English language, feminist translators such as Suzanne de Lotbinière-Harwood adopted what she calls a system of "neutralisation which is the process of creating synonyms for words or phrases which are otherwise sex-definite" (de Lotbinière-Harwood 1991: 113) and a process of "feminisation" of language which "goes beyond neutralization and desexization. It includes strategies such as avoiding pejorative words designating women, encoding new meaning in existing words and coining new words, often using etymology as a resource" (ibid.: 117-19).

Finally feminist writers and translators continue to develop and create new modes of expressions in order to challenge patriarchal biases in the English language. Their political acts are, however, often met with resistance and call to preserve conventional language use. De Lotbinière-Harwood gives as an example the word 'hystory,' which she coined to refer to 'l'histoire des 
femmes.' When her work was published, she was surprised to find that her publishers overlooked her word play and preserved the dominant language:

I made a compromise decision probably due to inexperience and contextual complexity: I translated l'histoire des femmes by the entirely redundant "women's hystory (sic)." The "sic" was intended to indicate that the y wasn't a typo. When the piece appeared, my political act had been changed into the perplexing "... women's history (sic)." The "(sic)" remained, no questions asked. Quel mess! (1991: 121)

Even though many of the strategies and techniques they have invented failed to be adopted and implemented in conventional language, feminist critique has helped to raise awareness about the impact of male-centered language on women's position in society and to stress the need to change the patriarchal norms and habits. This prompts the question whether women translators of the Quran will use similar techniques to present their feminine perspective or whether they will maintain conventional patriarchal English language in their translations of the sacred text of Islam. In the following sections, I will discuss two aspects of language, namely, the transfer of feminine imagery and the use of inclusive or gender-neutral language.

\section{Transferring Feminine Imagery from Arabic into English}

Like many other languages, Arabic has been described as a male-biased language that fails to express women's experiences and realities. In his book Arab Women Novelist, Joseph Zeidan argues that Arabic is a patriarchal language that is oppressive and exclusive of women. He insists that Arab female writers "must change this language significantly in order to find their own voices" (1995:2). Similarly, in her book Women, Gender, and Language in Morocco (2003), the writer Fatima Sadiqi criticizes the male bias in the Arabic language, which in her view aims at disempowering and silencing women. Borrowing Robin Lakoff's concept of women's language, Sadiqi argues that there is a difference between men's and women's language use and asserts that only equity in language could "gradually uproot the pervasive androcentricity" in the Arab society (2003:161). Furthermore, in order to challenge the status quo, a new wave of Arab women writers has recently started experimenting with an inclusive Arabic language. For instance, in a short novel published in the Lebanese magazine Zawaya (2007), the Palestinian writer and filmmaker Adania Shilbi uses the dual form instead of the generic masculine form, which is one of the patriarchal linguistic elements in the Arabic language. Indeed, Arabic uses masculine nouns and pronouns in the generic sense, and in a sentence masculine elements are placed before the feminine. Such grammatical 
rules, as many feminist writers and translators argued, give men priority over women. The Quranic language, which is slightly different from Modern Standard Arabic, uses the same rules and could therefore be viewed as patriarchal. However, many scholars such as Asma Barlas and Michael Sells insist that the Quranic language is gender neutral both in form and content. Barlas notes that the gender balance in the Quranic language "makes it clear that God shaped not only the language of the Divine Discourse but also its content in light of women's concerns" (Barlas 2002: 20). Michael Sells shares the same view and points out that:

Like all sacred texts of the classical period of religious revelations, the Quran was revealed in a society in which the public voice of leadership was largely male; thus, the social context of the revelation, as in the Bible or the Vedas, was largely a male domain. Yet the gender dynamic within the Quran contains an extraordinary balance that is constructed and modulated through sound figures. (Sells 1999: 5)

While the debate over the patriarchal or gender equal nature of the Quranic text continues, the problem faced by most translators of the Quran lies in the differences in gender agreements between the source and the target language. Arabic has "grammatical gender," which means that nouns are placed in classes not according to their meaning but according to their form. This form determines the way the word will behave grammatically as regards the agreement of adjectives, articles and pronouns. English has "natural gender." This means that gender is attributed not by form but by meaning (Simon 1996: 17). As a result of these differences, feminine images constructed and modulated through feminine nouns, pronouns and adjectives could become invisible and lose their gender-specific meanings in the target text. The translation of the term 'shams' (sun), a grammatically feminine term in Arabic, is a case in point:

Arabic transliteration of verse 91:1-4:

Wa ash-shamsi wa duhaha

Wa al-qamari 'itha talaha

Wa an-nahari 'itha jallaha

Wa al-layli 'itha yaghshaha

(1) By the Sun and her brightening

By the moon when it follows her

By the day when it displays her

By the night when it veils her

(Sells 1999:195)

(2) By the sun and his morning brightness

and by the moon when she follows him, 
and by the day when it displays him and by the night when it enshrouds him!

(Arberry 1955: 340)

(3) By the sun and its forenoon brightness,

And the moon when it follows it,

And the day when it exhibits its light,

And the night when it obscures it;

(Fakhry 1997: 412)

In the transliterated text, the letters ha, occurring at the end of each line, represent the feminine pronoun which refers to the word 'shams.' In addition to indicating the feminine gender, these letters create the rhyme in the verse, which helps the reader to imagine a "feminine gender figure." As Sells (1999:195) explains, the feminine pronoun, ha, is a sound that "anchors the sura [verse]" and "creates a sense of a feminine-gendered presence within a set of sliding or shifting referents (the sun, the sky and the earth and/or the sun, and then the soul)." This is why in his translation (example 1), Michael Sells maintains the feminine form of the original text by referring to the sun as 'her.' As in the Arabic text, the repetitive use of the pronoun and sound 'her' allows the reader to imagine a feminine gender figure. And even though the 'her' is never fully personified as a woman, the repetition of the feminine pronoun enforces such personification.

In the second example, John Arthur Arberry recreates the personification of the sun but overlooks the feminine imagery. He replaces the feminine pronoun ha with the masculine pronoun 'he' since, in English, the sun is normally thought of as masculine. As a result of this shift, the feminine sounds and imagery are lost and the dominant image in this version becomes that of a "masculine gender figure." Similar losses are encountered in the third example, where the translator Majid Fakhry overlooks the element of personification and fails to convey the feminine sounds and images created in the source text by replacing the feminine pronoun ha with the pronoun 'it.' The loss of feminine imagery in these two last examples demonstrates how gender-specific meanings constructed in the source text could easily be lost in the process of translation. It also highlights the importance of transferring the feminine form of nouns, pronouns and adjectives into the target text in order to reflect the gender balance intended in the original, especially that these feminine:

patterns create partial personifications - of a woman giving birth, conceiving, suffering, experiencing peace, or grieving at the loss of her only child- [...] These sound visions occur at theologically critical moments in the Quran and are vital to its suppleness and beauty in the original Arabic. (Sells 1999:195) 
As Sells points out, the absence of such feminine imagery in translation is particularly damaging because of the way Islam has been perceived in stereotypes about gender and the role of women in society (ibid.).

Furthermore, the loss incurred in the translation of the word shams and its pronoun highlights the role of gender-marking in language. Roman Jakobson has argued that grammatical gender can be used to convey specific meanings in poetry and mythology. In his view, grammatical gender, which is often perceived as an insignificant element in language for translation, plays a key role when the poet wishes to emphasize the gendered identities of the terms for the days of the week, the night and day (Jakobson 1959). Sherry Simon stresses the same point by stating that:

while grammarians have insisted on gender-marking in language as purely conventional, feminist theoreticians follow Jakobson in re-investing gendermarkers with meaning. The meaning which they wish to make manifest is both poetic and, especially, ideological. (Simon 1996: 18).

Although gender markers exercise a powerful imagery role, as argued by Jakobson and Simon, none of the four women translators of the Quran has attempted to transfer the feminine form of the pronoun ha into the target text. All four adopted a similar approach and, like Majid Fakhry, they failed to recreate the feminine imagery and personification created in the original Arabic text. Interestingly, Bakhtiar made an exception with words referring to women, where she uses the letter ( $\mathrm{f}$ ) to indicate their feminine gender. In the preface she introduces her strategy by stating that:

when words in a verse refer directly to a woman or women or wife or wives and the corresponding pronouns such as (they, them, those), I have placed an (f) after the word to indicate that the word refers to the feminine gender specifically. (2007: xli)

This technique described as compensation is often employed by translators to make up for linguistic and semantic losses between the source and the target language. It could be viewed as a textual or para-textual strategy depending on the tools employed by the translator. Hervey and Higgins distinguish several subcategories of compensation which include compensation in place, compensation in kind, compensation by footnoting, compensation by splitting $^{1}$ and compensation by merging (2008: 27-31). Although the compensation

1. Godard employed this strategy when she translated the title of Nicole Brossard's LAmer, this term is a neologism in French which contains three different words: mère (mother), mer (sea), and amer (bitter). Godard compensates for the polysemy of the source text by providing all the possible readings in the target texts. She uses graphological deviation and translates the title as: 
strategy can be easily identified in a wide range of translations, one subcategory seems to be frequently employed by feminist translators, namely the category of compensation in kind. This subcategory is concerned with losses in meaning incurred by differences in gender agreements between the source and the target language. Hevery and Higgins give as an example the problem of translating Dora Alonso's feminist short story Los gatos, where the opening sentence "la gata dilataba las pupilas en la oscuridad" could lose its feminist value if simply translated as 'the cat's eyes grew large/dilated in the darkness' To maintain the gender-based link between feline motherhood and human motherhood, a crucial element in the source text, Hervey and Higgins propose to compensate in kind by translating the feminine Spanish term 'la gata' as the 'she-cat' or as 'the mother cat.' Their suggestion recovers what they describe as an "unacceptable translation loss" (Hervey 2008: 28).

To overcome similar translation losses, feminist translators employ a variety of tools to compensate in kind. De Lotbinière-Harwood, for instance, uses graphical tools to make up for translation losses between the gendermarked French and the gender-unmarked English. In the French source text, Michèle Causse uses the silent letter 'e' to indicate the feminine form in the sentence "Nulle ne l'ignore, tout est langue," 'Nulle' is the feminine form of 'no one.' Because in the English language this word does not mark gender, de Lotbinière-Harwood uses a bold e in "one" to make up for the linguistic loss and to highlight the fact that the source text refers specifically to the feminine gender. She also uses the same technique to translate the sentence "une muette parle à un aveugle" as "a mute one speaks to a deaf one" (Simon 1996: 21). Similarly, Bakhtiar uses the compensation strategy to make up for the linguistic losses between the gender-marked Arabic and the English language. This is how she translates verse 2: 231 :

And when you divorce wives and they (f) are about to reach their(f) term, then hold them (f) back honourably or set them (f) free honourably but hold them (f) not back by injuring them so you commit aggression (Bakhtiar 2007: 41)

\footnotetext{
The Sea our mothers

"The Sea Our Mother" + "Sea (S)mothers" + "(S) our Mothers" Von Flotow describes this same technique as the feminist strategy of "supplementing" (von Flotow 1991:76).
} 
The presence of the letter (f) in Bakhtiar's text compensates for the gender differences on two levels: meaning conveyance and visual impact. In terms of meaning the letter ( $f$ ) indicates to the reader which words are meant to be feminine. Readers looking at Bakhtiar's text can easily gather that the subject of these verses concerns the feminine gender, thanks to the letter (f). In terms of visual impact, the unusual presence of the letter (f) creates a stronger effect on the reader and stresses the feminine visibility in the text, which is the ultimate goal for feminist translators as asserted by de Lotbinière-Harwood, who in her translation of Lise Gauvin's Lettres d'une Autre "used every possible translation to make the feminine visible. Because making the feminine visible in language means making women seen and heard in the real world" (1990: 9).

The compensation technique plays, however, another key role in Bakhtiar's rendition, which is to preserve, reflect and mirror the structure and linguistic patterns of the original text. In the introduction, Bakhtiar notes that previous translations "put emphasis on interpreting a Quranic verse without precisely representing the original Arabic word." She then tells us that one of her main aims is to be "as close as possible to the original text" (2007: i). Bakhtiar's aim to remain faithful to the original constitutes one of the major areas where her translational approach diverts and conflicts with feminist translation practice. ${ }^{2}$ Her use of the letter (f) could be interpreted as an attempt to make the feminine visible. It could also be simply a strategy to mirror the source text. In both cases this technique could be a first step towards compensating for gender agreement differences between Arabic and English and for ensuring that the feminine gender of nouns, pronouns and verbs is visible in the target text. Furthermore, this technique could allow translators to transfer the "gender balance" into the translated text, which constitutes one of the main challenges encountered when translating the Quranic text. Other challenges lay in the translation/non translation of patriarchal linguistic elements in the sacred text. What strategies could women translators of the Quran employ to deal with the predominant use of masculine nouns and pronouns in the source and the target language?

\section{Male-Centered versus Gender Neutral or Inclusive Language}

The patriarchal tone in many ancient sacred texts has been the focus of great deal of controversy within the field of religious text translation. One of the

2. See Hassen, Rim. (2008) "Feminist Translation Strategies and the Quran: A Study of Bakhtiar's Translation." <http://www2.warwick.ac.uk/fac/arts/ctccs/news/confpublications> 
main persisting questions is how to explain and justify what is today considered as an excessive use of male-centred language. Should the patriarchal elements be considered as a part of the message of the original? Or are they merely part of the language and context through which the message was communicated? In other words, is the patriarchal language of sacred religious texts prescriptive or incidental? If so, where should the translator's allegiance lay, with the source text or with his/her modern day target readers? In answering these questions, a number of Bible scholars such as Vern S. Poythress and Wayne A. Grudem have argued that masculine generic terms are an essential part of the grammatical structure of the biblical languages. They claim that Hebrew and Greek are perfect and precise languages created especially for divine communication. They both believe that:

everything that the Bible says, and even the manner in which it says it, involves subtle moral implications, because the Bible is, among other things, a definitive example of morally pure speech. The translator's job is not merely to make sure that the most explicit teaching subjects are conveyed in English. His job is to carry over all the nuances that he possibly can. If the nuances are there in the original, they belong in the translation, whether or not they are "intended" in some artificially narrow sense. (2000: 192-193)

Poythress and Grudem's notion of "pure speech" seems to suggest that it is God's intention to use masculine generic terms in order to express male nuances and connotations. They therefore insist that translators must mirror patriarchal elements in the target language. Interestingly, the feminist theologian, Phyllis Bird, shares similar views and considers it essential to maintain the patriarchal tone of the original text. She argues that the Bible translator's task is to enable a modern audience "to overhear an ancient conversation rather than to hear itself addressed directly" (1988: 91). She also declares that she is "not even certain that the translator is even obliged to make the modern reader understand what is overheard" (ibid.: 91). Even though Bird seems to agree with Poythress and Grudem's philosophy of translation and their call for maintaining the patriarchal elements in translation, she has a completely different reason. Her main aim is to expose the male bias in religious texts, since covering the male-centred language masks the deeper underlying issues. Bird also argues that the androcentric nature of the biblical language must be laid bare and must be recognised, as a sign of its historically and culturally limited nature (1988: 90).

Poythress, Grudem and Bird's position on the Bible translator's task contradicts sharply with the "functional equivalence" school of Eugene Nida, which argues for an actualization of the ancient text, making it come to speak to the reader as if it were written for a contemporary audience (Nida and 
Waard 1986). This philosophy of translation which focuses on the target readers has allowed many Bible translators to adjust the language of religious text to address modern readers' concerns. The NRSV, for instance, adopted various strategies to produce a translation that is sensitive and inclusive of women. Among the measures they adopted is to replace singular masculine pronouns by plural ones. Generic terms such as 'humankind,' 'human,' 'human being' and 'person' were used instead of the masculine word 'man.' Hebrew and Greek terms traditionally rendered 'fathers' were translated as 'parents' or 'ancestors' and the Greek and Hebrew terms for 'sons' were rendered as 'children,' 'descendants,' or with other inclusive terms (Strauss 1998:40-3).

In the field of Quran translation the issue of gender-inclusive or neutral language is not as visible as in Bible translation. One of the reasons could be that most English translations of the Quran are source text oriented. In fact, almost all existing English translations of the Quran, including those by or with the participation of women, use masculine nouns and pronouns in the generic sense. The only exception is probably the Light of Dawn, in which the translator, Camille Adams Helminski, shows a clear sensitivity to women's concerns by making some adjustments to contemporary norms. Her position is made clear from the start, as she explains in the preface:

Regarding the use of pronouns $[\ldots]$ in some cases I have used the feminine pronoun rather than the masculine for both the human being and occasionally in reference to God so that those reading these selections may have a reminder that within the Universe and understanding of the Quran, God is without gender... In God's sight men and women are equal. (2000: xiv)

Although the Arabic text uses masculine generic nouns and pronouns, Helminski uses the combination "he/she" as well as the generic "he" to refer to human beings and to the Supreme Deity. Her linguistic choice makes it clear that women and men are equally addressed by the Quranic text. Interestingly, Bakhtiar did not adopt a similar strategy, even though in her introduction she clearly uses inclusive language. She for instance wrote that "a person considers himself or herself a good example of submission if he or she follows the example or sunnah of the Prophet" (2007: li). However, within the translation Bakhtiar seems to revert to patriarchal language by using generic 'he' to refer to both genders. This is how the four translators rendered verse 45:15:

(1) Whoever does a good deed - it is for himself; and whoever does evil - it is against it [i.e. the self or soul]. Then to your Lord you will be returned. (Saheeh International [Umm Muhammad] 1995: 705)

(2) If anyone does a righteous deed it is to his/her own benefit. If he/she does harm it works against his/her soul. In the end you will all be brought back to your Sustainer. (Helminski 2000: 140) 
(3) If a person does good deeds, it is for his own benefit and if he does evil, it will be against himself, since at the end all of you will be returned to your Creator. (Saffarzadeh 2006: 931)

(4) One who acts in accord with morality, it is for his own self; and whoever does evil, he is against his own self. Then to your Lord you shall be returned. (Bakhtiar 2007: 579-580)

Umm Muhammad, Saffarzadeh and Bakhtiar made no attempts to adjust the patriarchal tone of the above verse. All three seem to recognize that it is natural and idiomatic in Arabic to use the masculine singular pronouns as inclusive of women, and chose therefore to maintain the same usage in English. Helminski, on the other hand, used the combination "he/she," to soften the patriarchal tone and to highlight the inclusionary intention of the source text. Furthermore, it is worth pointing out that this particular verse illustrates perfectly Michael Sells' notion of "gender balance" within the Quranic text. In the following transliterated Arabic text, the grammatically feminine term nafs, meaning 'soul' or 'being' is mentioned in two different occasions. In the first, it is placed before the masculine pronoun he, in the second occasion its feminine pronoun ha is placed after the masculine verb, as illustrated in the following transliteration of the Arabic text:

man amila salihan fa linafsihe (feminine + masculine) wa man asaa-a fa 'alay-

ha, (masculine + feminine) thum-ma ilaa rab-bikum turja'uun (plural).

The gender balance is created through sound and word order. Through sound since the first part of the verse ends with a masculine sound he, while the second part ends with a feminine sound ha. Similarly, the word order contains in the first part of the sentence, a feminine noun followed by a masculine pronoun. In the second part, a masculine verb is followed by a feminine pronoun. This gender balance is supported at the end of the verse, where a plural form is used to include both the feminine and the masculine. Borrowing de Lotbinière-Harwood's use of the bold format and Bakhtiar's use of the letter (f), this verse could be translated as follows:

Whoever does a good deed it is for his own self (f) and whoever does evil, he does it against her. Then to your Creator you will all be returned.

This alternative translation reflects how feminine and masculine pronouns and imagery are equally divided in the original Arabic text in order to create a gender balance through sound and vision, which are both difficult to transfer in the English text when using conventional linguistic tools.

Regarding the translation of masculine exclusive nouns such as 'man,' 'mankind,' 'father' and 'son,' the four translators seem to be equally divided in their approach. In the following examples (verse 2:21), for instance, there are 
clearly two different tendencies; Umm Muhammad and Saffarzadeh seem to overlook the problem by using male-centered language, while Helminiski and Bakthiar consistently avoid exclusionary terms:

(1) O mankind, worship your Lord, who created you and those before you, that you become righteous. (Umm Muhammad 1995: 4)

(2) O, you people! Worship your Creator\&Nurturer, Who created you and Created those who came before you,

So that [through worshipping], you may Become pious. (Saffarzadeh 2006: 7)

(3) O Humankind!

Worship your Sustainer, who has created you

And those who lived before you,

So that you remain conscious of the One. (Helminski 2000: 2)

(4) Oh humanity! Worship your Lord

Who created you

And those that were before you

So that perhaps you would be God-fearing. (Bakhtiar 2007: 3)

The key term in this verse is the plural generic Arabic word 'an-nas' meaning human beings or people. Helminski and Bakhtiar have avoided male-oriented language and chose respectively 'humankind' and 'humanity.' Umm Muhammad and Saffarzadeh, on the other hand, are not consistent in their translations of this specific term. For instance, in their translation of the same word in verse 2:164, they respectively use 'mankind' and 'people' (30) (43). This inconsistency and the use of the word 'mankind' suggest that they have no objection against using masculine generic terms and nuances. This becomes clearer in their translation of verses 90:1-7:

(1) I swear by this city [i.e., Makkah]

And you, [O Muhammad] are free of restriction in this city

And [by] the father* and that which was born of [him]

We have certainly created man into hardship.

Does he think that never will anyone overcome him?

* Said to be Adam. (Umm Muhammad 1995: 886)

(2) I swear by this [Makkah] City

And you are native of this city

And the Father and the Son*

Verily, We created man [Adam] in

The space [somewhere between the sky and the earth]

Does man think that Allah the One [the Ahad] has no power over him?

* Ibrahim and Ismail, who built the Sacred House of Ka'bah in Makkah City

by Allah's command. (Saffarzadeh 2006: 1164) 
(3) I call to witness this land

In which you are free to dwell

And the bond between parent and child

Truly, we have created the human being to labor and struggle

Does he think that no one has power over him. (Helminski 2000: 196)

(4) No! I swear by this land;

You are a lodger in this land;

By one who was your parent,

And was procreated

Truly We created the human being in trouble.

What? Assumes he that no one has power over him? (Bakhtiar 2007: 697)

Key terms in this verse are 'walid' and 'insan.' Walid is grammatically a masculine word, meaning a father, but could be used in generic sense to refer to both parents. Umm Muhammad and Saffarzadeh translated it in its masculine sense and inserted footnotes giving further information on the person/s concerned. Umm Muhammad informs the reader that walid refers to Adam, the Deity's first creation. The problem with this specification is that it confirms the patriarchal interpretation of creation, in which the first being was male. The underlying message from this belief is that woman was derived from man and is therefore inferior and unequal to him. As Simon pointed out, recent feminist and moderate re-readings of the nature of the first creation contest the exclusively masculine identity of the first being, because it is demeaning for women (1988: 118-130). While Saffarzadeh provides a different specification of the same word, her interpretation is no less patriarchal. By suggesting that the "father" and the "son" refer to Abraham and Ishmael, who built the Kaba, the holiest religious site of Islam, Saffarzadeh places the male at the centre of religion and at the same time excludes women. Moreover, when translating the masculine second key term 'insan,' meaning human being, Umm Muhammad and Saffarzadeh both chose the word 'man.' Their choice reveals a male-biased understanding of this verse and exposes many of the patriarchal elements it contains, such as the assumption that the generic human is male and that man is primary creation while woman is secondary. This raises the question whether their use of patriarchal language is intentional or unintentional?

To answer this question it is necessary to look at the social, cultural and religious environment surrounding the translators, who both live/d in Muslim majority countries. Umm Muhammad, an American convert to Islam, lives and works in Saudi Arabia. Saffarzadeh, an Iranian writer and poetess, received part of her education in the United States, but lived and worked in Iran until she died in 2008. Saudi Arabia and Iran are widely known for their 
conservative and traditionalist Islamic regimes, where patriarchal interpretations of sacred texts are maintained and reinforced by strict adherence to classical religious sources, interpreted, transmitted and collected mostly by male scholars. Umm Muhammad and Saffarzadeh's linguistic choices could, therefore, have been heavily influenced by the patriarchal societies in which they both live/d. They may have internalised male-centred linguistic norms and unintentionally reproduced them in their translations. This is visible in their introductions and prefaces: Umm Muhammad for instance writes that "this divine message was revealed to conform and renew the relationship between man and his Creator" (Umm Muhammad: ix). Furthermore, it is also possible that the two translators have intentionally chosen to use male-centred language. They may have shared similar views with Poythress and Grudem in considering patriarchal language an essential part of the meaning and the message of sacred text. They subsequently adopted a similar philosophy of translation whereby the translator's obligation must lay with the source text rather than with the target reader, which could explain the use of male-centred language in both their translations. In any case, Umm Muhammad's and Saffarzadeh's linguistic choices could have serious implications in their target culture since it seems to oppose the norms of Western society and its strive for an egalitarian use of language. Most importantly it seems to conflict with decades of women's struggle for gender equality in and through language.

Helminski and Bakhtiar, on the other hand, have attempted to avoid women's exclusion by using inclusive terms. Instead of using 'father' and 'son,' Helminski, renders the same expressions as 'parent' and 'child.' Bakhtiar uses the same inclusive word 'parent' to translate the term walid. In translating the word 'insan' they both use the inclusive expression 'human being.' Their linguistic choices show their understanding of the problem of male-centered language in sacred texts and indicate an attempt to adjust the language of the original text to the norms of the Western society in which they both live. Moreover, Helminski and Bakhtiar seem to be aware of the different debates around the use of patriarchal language, especially that most of the techniques they have adopted share similarities with those employed by feminist translators and supporters of inclusive language in Bible translation.

\section{Conclusion}

Taking into consideration feminist writers and translators' criticism of malebias in conventional language and their belief that a more inclusive language could affect male/female relation in society, this paper sought to show how women translators of the Quran have dealt with the problem of translating 
patriarchal language in sacred religious texts. The two aspects of language discussed here, namely the problem of gender agreement differences and the use of exclusive language have shown that Umm Muhammad and Saffarzadeh have consistently maintained patriarchal elements in the target text, which could be viewed as a direct influence of the patriarchal societies and cultures in which they both live/d.

Helminski and Bakhtiar, on the other hand, have employed interesting strategies to deal with the "gender balance" challenge and the patriarchal tone of the sacred text. By introducing the letter (f) Bakhtiar attempted to ensure feminine visibility in the target text and to compensate for some of the linguistic losses between the gender marked Arabic and the gender unmarked English language. Even though Helminski did not address the problem of transferring feminine imagery and nuances from Arabic into English, she consistently sought to adjust and soften the patriarchal tone in the target text by using inclusive nouns and pronouns to refer to human beings and to the Supreme Deity.

Finally, though relatively newly emerged, English Quran translations by women seem to have already left its mark on this field by incorporating feminine elements and revealing new feminine perspectives. With probably more works to come, it is possible that women's involvement could help create new methods, strategies and maybe new egalitarian linguistic norms for translating the sacred text of Islam.

\section{References}

ARBERRY, John Arthur. (1955) The Koran Interpreted. London: Allen \& Unwin.

BAKHTIAR, Laleh. (2007) The Sublime Quran. Kazi Publications.

BARLAS, Asma. (2002) "Believing Women" in Islam: unreading patriarchal interpretations of the Quran. Austin, TX: University of Texas Press.

BIRD, Phyllis A. (1988) "Translating Sexist Language as a Theological and Cultural Problem." Union Seminary Quarterly Review 42:1. pp 89-95.

CAMERON, Deborah. (1985) Feminism and Linguistic Theory. London: Macmillan.

DALY, Mary. (1974) Beyond God the Father: toward a philosophy of women's liberation. Boston: Beacon Press.

De LotBinIĖRE-HARWOOD, Susanne. (1990) Letters from Another. Toronto: Women's Press.

ElGIN, Suzette Haden. (2000) Native Tongue. New York : Feminist Press.

FAKHRY, Majid. (1997) The Qur'an: a Modern English Version. Reading: Garnet.

HeLminski, Camille Adams. (2000) The Light of Dawn: Daily Readings from the Holy Qur'an. Boston: A Shambhala Threshold Book. 
Hervey, Sándor; Ian Higgins \& Louise Haywood. (2008) Thinking Spanish Translation: a Course in Translation Method, Spanish to English. London: Routledge.

JAKOBSON, Roman. (1959) "On linguistic aspects of translation". In: Brower, R. (ed.) On Translation. Cambridge MA: Harvard University Press.

LAKOFF, Robin. (1975) Language and Woman's Place. New York: Harper \& Row.

LiviA, Anna. (2001) Pronoun Envy: Literary Uses of Linguistic Gender. Oxford: Oxford University Press.

Miller, Casey \& Kate Swift. (1977) Words and Women. Garden City, N.Y: Doubleday/Anchor.

Plaskow, Judith. (1990) Standing Again at Sinai: Judaism from a Feminist Perspective. San Francisco: Harper \& Row.

Poythress, Vern S. \& Wayne A. Grudem. (2000) The Gender-Neutral Bible Controversy: Muting the Masculinity of God's Words. Broadman \& Holman Publishers.

SAdiQI, Fatima. (2003) Women, Gender and Language in Morocco. Leiden and Boston: Brill.

SAFFARZADEH, Tahereh. (2006) The Holy Quran: Translation with Commentary. Tehran: Alhoda.

SAHEeH International. (1997) The Quran, Arabic Text with Corresponding English Meaning Riyadh: Abulqasim Publishing House.

SELLS, Michael. (1999) Approaching the Qur'an: the Early Revelations. Ashland, OR: White Cloud Press.

SiMON, Sherry. (1996) Gender in Translation: Cultural Identity and the Politics of Transmission. London: Routledge.

Spender, Dale. (1980) Man Made Language. London: Pandora.

STRAUSS, Mark. (1998) Distorting Scripture? The Challenge of Bible Translation \& Gender Accuracy. Downers Grove, IL: InterVarsity.

Von Flotow, Luise. (1997) Translation and Gender: Translating in the "Era of Feminism." Manchester: St. Jerome.

Von Flotow, Luise. (1991) "Feminist Translation: Contexts, Practices, Theories." TTR: Traduction Terminologie Rédaction 4(2). pp 69-84.

ZEIDAN, Joseph. (1995) Arab Women Novelists: the formative years and beyond. Albany: State University of New York Press. 